\title{
The significance of TRIP11 and T3 signalling pathway in renal cancer progression and survival of patients
}

\author{
Znaczenie TRIP11 i ścieżki sygnałowej 3,5,3'-trójjodotyroniny w progresji raka \\ nerki oraz wpływ na czas przeżycia chorych z rakiem nerki
}

\author{
Piotr Popławski', Agnieszka Piekiełko-Witkowska', Alicja Nauman ${ }^{1,2}$ \\ ${ }^{1}$ Centre of Postgraduate Medical Education, Department of Biochemistry and Molecular Biology, Warsaw, Poland \\ ${ }^{2}$ Laboratory of Human Cancer Genetics, Centre of New Technologies, University of Warsaw, Warsaw, Poland
}

\begin{abstract}
Introduction: TRIP11 is a multifunctional protein localising either to Golgi apparatus, acting as a golgin, or in the nucleus, acting as coactivator of transcription mediated by thyroid hormone receptor (THR) and hypoxia-inducible factor (HIF). Triiodothyronine (T3) regulates nuclear localisation of TRIP11 by inducing its phosphorylation. The exact mechanism of this regulation is unknown. The expressions of THR and HIF are disturbed in various cancers, including renal cell cancer (RCC). In this study, we aimed to analyse: 1) the mechanism of T3-dependent subcellular localisation of TRIP11; and 2) the significance of TRIP11 and T3 signalling pathway in RCC progression. Materials and methods: TRIP11 subcellular localisation was analysed using immunocytochemistry in RCC-derived cell line treated with T3, T3-agarose, and PI3K inhibitor, wortmannin. The expressions of TRIP11 and genes involved in T3 signalling and hypoxia were investigated using qPRC in 36 pairs of RCC tumour-control samples, followed by validation/survival analysis in an independent cohort of $>450$ renal cancer patients.

Results: Wortmannin disrupted T3-dependent nuclear transport of TRIP11. T3-agarose did not change TRIP11 localisation, precluding extracellular T3-mediated mechanism. The expressions of TRIP11, HIF-1 $\beta$, THRA, THRB, FURIN, VEGFA, and GLUT1 were disturbed in renal cancer. Expressions of TRIP11 and HIF-1 $\beta$ correlated with tumour grades. Decreased expressions of TRIP11, THRA, and THRB correlated with poor survival of RCC patients.

Conclusions: 1. T3 induces nuclear TRIP11 localisation via PI3K-dependent mechanism. 2. disturbed expression of T3 signalling pathway genes correlates with RCC progression. The specific mechanisms by which altered T3 signalling may contribute to RCC progression require further investigation. (Endokrynol Pol 2017; 68 (6): 631-641)
\end{abstract}

Key words: RCC, thyroid hormones, hypoxia, TRIP11

\section{Streszczenie}

Wstęp: TRIP11 jest wielofunkcyjnym białkiem lokalizującym się w aparacie Golgiego lub w jądrze komórkowym, gdzie działa jako koaktywator transkrypcji zależnej od receptorów hormonów tarczycy (THR) i czynnika indukowanego hipoksją (HIF). 3,5,3'-trójjodotyronina (T3) reguluje subkomórkową lokalizację TRIP11 wpływając na jego fosforylację. Dokładny mechanizm tej regulacji jest jednak nieznany. Ekspresja THR i HIF jest zaburzona w nowotworach, w tym w raku nerkowokomórkowym (RCC). Celem pracy było poznanie: 1 . mechanizmu, za pośrednictwem którego T3 indukuje zmiany w lokalizacji TRIP11; 2 . znaczenia TRIP11 i ścieżki sygnałowej T3 w progresji RCC. Materiały i metody: Lokalizację komórkową TRIP11 określano immunocytochemicznie w wywodzącej się z RCC linii komórkowej traktowanej T3, T3-agarozą i wortmaniną (inhibitorem kinazy PI3K). Ekspresja TRIP11 i genów zaangażowanych w odpowiedź komórki na T3 i hipoksję badano metodą qPCR w 36 parach guz RCC-kontrola nienowotworowa. Walidację wyników analizy qPCR oraz analizę czasu przeżycia prowadzono na niezależnej kohorcie chorych z RCC $(\mathrm{n}>450)$.

Wyniki: Wortmanina blokuje indukowany przez T3 transport TRIP11 do jądra komórkowego. T3-agaroza nie wpływa na lokalizację TRIP11, co wyklucza zewnątrzkomórkowy mechanizm działania T3. Ekspresja TRIP11, HIF-1 $\beta$, THRA, THRB, FURIN, VEGFA i GLUT1 jest zaburzona w RCC. Ekspresja TRIP11 i HIF-1 $\beta$ koreluje ze stopniem zaawansowania nowotworu. Obniżona ekspresja TRIP11, THRA i THRB koreluje z krótszym czasem przeżycia chorych z RCC.

Wnioski: 1. T3 zmienia lokalizację TRIP11 na jądrową poprzez mechanizm zależny od kinazy PI3K. 2. Zaburzona ekspresja genów ścieżki T3 koreluje z czasem przeżycia chorych z RCC. Dokładny mechanizm, za pośrednictwem którego T3 może wpływać na progresję RCC wymaga dalszych badań. (Endokrynol Pol 2017; 68 (6): 631-641)

Słowa kluczowe: $R C C$, hormony tarczycy, hipoksja, TRIP11

Alicja Nauman, Centre of Postgraduate Medical Education, Department of Biochemistry and Molecular Biology, Marymoncka 99/103, 01-813 Warsaw, Poland; Laboratory of Human Cancer Genetics, Centre of New Technologies, University of Warsaw, S. Banacha 2c, 02-097 Warsaw, Poland tel. +48225543697, e-mail: alicja.nauman@cent.edu.pl

Agnieszka Piekiełko-Witkowska, Centre of Postgraduate Medical Education, Department of Biochemistry and Molecular Biology, Marymoncka 99/103, 01-813 Warsaw, Poland, tel. +48225693717, email: apiekielko@cmkp.edu.pl 


\section{Introduction}

Thyroid hormone 3,5,3'-triiodothyronine (T3) is an important regulator of key cellular processes, including proliferation, apoptosis, and metabolism. The proteins involved in T3 signalling pathway include thyroid hormone receptors (THR) that regulate expression of target genes in a T3-dependent manner. Previous studies revealed that T3-THR actions are disturbed in cancers, including renal tumours [1-4], and actively contribute to the process of cancerogenesis. The transcriptional activity of THRs is regulated by co-regulatory proteins, including TRIP11.

TRIP11 is a multifunctional protein involved in functioning of Golgi apparatus and regulation of gene expression. Coincidently with its different functions, TRIP11 can localise either to Golgi apparatus, acting as a golgin [5], or the nucleus, acting as coactivator of transcription. TRIP11 (also named TRIP230 and GMAP-210) was initially discovered as a protein interacting with retinoblastoma protein $(\mathrm{Rb})$ and THR [6]. In the presence of T3, TRIP11 binds THRs and enhances THRdependent transcription. Furthermore, TRIP11 acts also as a coactivator of hypoxia-inducible factor (HIF). By binding to ARNT (HIF-1 $\beta$ ), a dimerisation partner of HIF-1 $\alpha$, TRIP11 contributes to the activation of HIF-1 $\alpha$-regulated genes [7]. The coactivator function of TRIP11 is inhibited by retinoblastoma protein that interacts with TRIPI11 and interferes with its binding to THRB and ARNT [8].

The transcription-related functions of TRIP11 indicate that it acts on the crossroads of two important signalling pathways, induced by hypoxia and thyroid hormones. Remarkably, both these pathways are involved in carcinogenic process. Hypoxia and activation of HIFs are a hallmark of solid tumours, resulting in stimulation of multiple genes that promote cancer progression [9]. Likewise, T3 and its receptors also influence multiple genes involved in cancer development and progression $[1,10,11]$. Remarkably, both these pathways share common gene targets, such as VEGF (vascular endothelial growth factor) or GLUT1 (glucose transporter 1) [12-15].

The knowledge of mechanisms that regulate functioning of TRIP11 is thus important for understanding the tumour-related alterations in signalling pathways induced by hypoxia and T3. The activity of TRIP11 in the cell highly depends on its subcellular localisation. Remarkably, it was shown that $\mathrm{T} 3$ regulates nuclear localisation of TRIP11 by inducing its phosphorylation [16]. The exact mechanism of this regulation is, however, unknown.

Regarding the significance of TRIP11 in the regulation of two signalling pathways important for cancer initiation and progression, in this work we aimed to analyse the mechanism of T3-induced cellular localisation of TRIP11. Furthermore, taking into consideration that both TRIP11-related pathways (induced by hypoxia and T3) are disturbed in renal cancer, we also explored the network of correlations between the genes involved in hypoxia and T3 signalling as well as the significance of TRIP11 and T3 signalling pathway in the progression of this tumour.

\section{Material and Methods}

\section{Cell culture and immunocytochemistry}

Caki-2 cells (ATCC - HTB-47) were cultured according to manufacturer protocol. $0.4 \times 10^{5}$ cells were seeded on $\Phi 12-\mathrm{mm}$ ethanol sterilised cover slides (Carl Roth $\mathrm{GmbH}$ Karlsruhe, Germany) placed in 24-well plates, and cultured in medium supplemented with charcoalstripped FBS (Sigma-Aldrich, St. Louis, MO, USA). After 24-h incubation the medium was renewed and cells were treated for one hour with $100 \mathrm{nM}$ wortmannin (Sigma-Aldrich, St. Louis, MO, USA) or vehicle. Medium was renewed and T3 (Sigma Aldrich), T3-agarose (MPBiomedicals, Eschwege, Germany), or vehicle was added. Following one hour of treatment the cells were fixed with $4 \%$ paraformaldehyde, rinsed with PBS, incubated $(3 \times 5$ minutes) with detergents [0.5\% saponin and $0.5 \%$ Triton X-100 (Sigma Aldrich)], and incubated for one hour in blocking buffer [10\% horse serum and 0.3\% Triton X-100 in PBS (Sigma Aldrich)]. Then cells were incubated overnight at $4^{\circ} \mathrm{C}$ with anti-TRIP11 antibody (BD Biosciences, Franklin Lakes, NJ, USA) diluted 1:50 in PBS with $2 \%$ horse serum, and 0.3\% Triton X-100. The slides were washed $(3 \times 5$ minutes) with washing buffer $(2 \%$ horse serum and $0.3 \%$ Triton X-100 in PBS), incubated for one hour with blocking buffer, and incubated for 20 minutes with secondary anti-mouse antibody conjugated with fluorophore $\mathrm{Cy} 2$ (Abcam, Cambridge, UK). Following additional washes $(3 \times 5$ minutes) with washing buffer, the cells were incubated for five minutes with DAPI (100 ng/ml) (Sigma Aldrich) in PBS, then washed again and fixed on slides with Fluoromount (Sigma Aldrich), dried, and observed with an Axio Observer D1 (Carl Zeiss, Berlin, Germany) equipped with a $100 \mathrm{X}$ oil-immersion objective.

\section{RNA isolation and cDNA synthesis}

RNA from RCC (renal cell carcinoma) tumours of clear cell pathology $(n=36)$ and matched-paired control samples $(\mathrm{n}=36)$ with no signs of tumour infiltration was obtained from the RNA Bank deposited at the Centre of Postgraduate Medical Education at the Department of Biochemistry and Molecular Biology. The use of tissue samples was approved by the local Bioethical Committee (no. 18/PB/2012 and no. 75/PB-A/2014). 
Reverse transcriptions were performed on $100 \mathrm{ng}$ of RNA using Revert Aid H Minus First Strand cDNA Synthesis Kit and random hexamers (Thermo Fisher Scientific, Rockford, IL, USA) according to the manufacturer's instructions.

\section{Real-time quantitative PCR}

Real-time quantitative PCR (qPCR) was performed using Taqman probes (Thermo Fisher Scientific) designed to detect 18SRNA (Hs03928985_g1), ARNT (Hs00231048_m1), FURIN (Hs00965485_g1), HPRT (HS-02800695), SLC2A1 (GLUT1) (Hs00892681_m1), THRA (Hs00268470_m1), THRB (Hs00230861_m1), TRIP11 (Hs00188542_m1), VEGFA (Hs00900055_m1), and TaqManUniversal Master MiX II (Thermo Fisher Scientific), according to the manufacturer's instructions.

\section{Statistical analysis}

Statistical analysis was performed with GraphPad Prism 5.00 for Windows (GraphPad Software, San Diego, CA, USA) using the Shapiro-Wilk normality test, Wilcoxon matched pair signed rank test, paired t-test, 1-way ANOVA with Bonferroni multiple comparisons post-test, and Kruskal-Wallis test with Dunn's Multiple Comparison Test. $\mathrm{P}<0.05$ was considered statistically significant. Survival rate analysis was performed as described previously [17], using the SurvExpress platform [18] and data retrieved from TCGA (https://tcga-data. nci.nih.gov, [19]).

\section{Results}

T3 induces nuclear TRIP11 localisation via PI3K-dependent mechanism

In agreement with the previous study [16] treatment of Caki-2 cells with T3 resulted in translocation of TRIP11 from Golgi complex to the nucleus (Fig. 1). We hypothesised that this T3 effect could be mediated by PI3K, previously shown to be activated by thyroid hormone [20,21]. To test this hypothesis, we pre-treated the cells with specific PI3K inhibitor, wortmannin. This treatment completely abolished the T3 effect on TRIP11 localisation (Fig. 1B).

\section{T3 effect on TRIP11 is not mediated by membrane-bound receptors}

T3 activates PI3K pathway by two mechanisms: either by THRB-mediated activation of $\mathrm{p} 85 \alpha$ PI3K subunit in the cytoplasm [21] or by the mechanisms involving the membrane receptor, integrin $\alpha v \beta 3$ [23]. To test the latter possibility, Caki-2 cells were cultured in the presence of T3-agarose, which precludes intracellular T3 actions. None of the five tested T3-agarose concentrations resulted in translocation of TRIP11 to the nucleus (Fig. 2).
This indicated that the effect of T3 on TRIP11 does not involve membrane receptors.

\section{Expressions of TRIP11 and ARNT are disturbed in renal cancer}

TRIP11 is a coactivator of signalling pathways induced by T3 and hypoxia [6-8]. Therefore, we analysed the expression TRIP11, as well as ARNT and genes involved in T3-signalling pathway in renal tumours. We also addressed the expression of FURIN, VEGFA, and GLUT1, known to be commonly regulated by HIFs and thyroid hormone pathway [12, 13, 15, 24, 25].

The expression of TRIP11 mRNA was statistically significantly $\left(\mathrm{p}=1.5 \times 10^{-3}\right)$ decreased -2.01 fold in RCC tumour samples when compared with matchedpaired controls (Fig. 3). In agreement with previous studies [2-4], the expressions of THRA and THRB were also significantly reduced in renal tumours $(-1.27$ fold $\mathrm{p}=2.0 \times 10^{-2},-4.67$ fold $\mathrm{p}<1.0 \times 10^{-4}$, respectively) The expression ARNT trended to increase (1.22 fold) in RCC tumours; however, this change was not statistically significant (Fig. 3).

Next, we analysed the expression of genes that are known targets of both, hypoxia- and T3-induced pathways. The expression of VEGFA (4.56 fold) and GLUT1 (3.96 fold) was statistically significantly ( $\mathrm{p}=$ $5.0 \times 10^{-4}$ and $\mathrm{p}<1.0 \times 10^{-4}$, respectively) induced in RCC tumours when compared with control samples (Fig. 3). There was a trend for decreased expression of FURIN (-1.95 fold); however, it did not reach statistical significance $\left(p=8.1 \times 10^{-2}\right)$ (Fig. 3). Remarkably, similar changes in expression of investigated genes were also confirmed on independent cohort of 534 RCC tumours and 72 non-tumorous controls (data obtained from TCGA, [19]) (Supplementary Fig. 1).

\section{The expressions of genes involved in T3 signalling and hypoxia are correlated in RCC tumours}

To see the potential changes in the network of interactions between T3 signalling and hypoxia, we analysed correlations between the expression levels of studied genes. In agreement with known cooperation of the analysed genes, we found that in control samples the expression of TRIP11 was highly correlated ( $\mathrm{r}$ Spearman $>0.75, \mathrm{p}<3.0 \times 10^{-8}$ ) with expressions of THRA, THRB, ARNT, FURIN, VEGFA, and GLUT1. Strikingly, in tumour samples TRIP11 did not correlate with VEGFA and GLUT1 (Fig. 4 and Supplementary Fig. 2). Similarly, the correlations between THRs and ARNT, VEGFA, and GLUT1 were much weaker or even lost in tumour samples comparing to controls (Fig. 4). These results possibly suggested that in RCC tumours the expression of VEGFA and GLUT1 might not be further controlled by $\mathrm{T} 3$ signalling. 

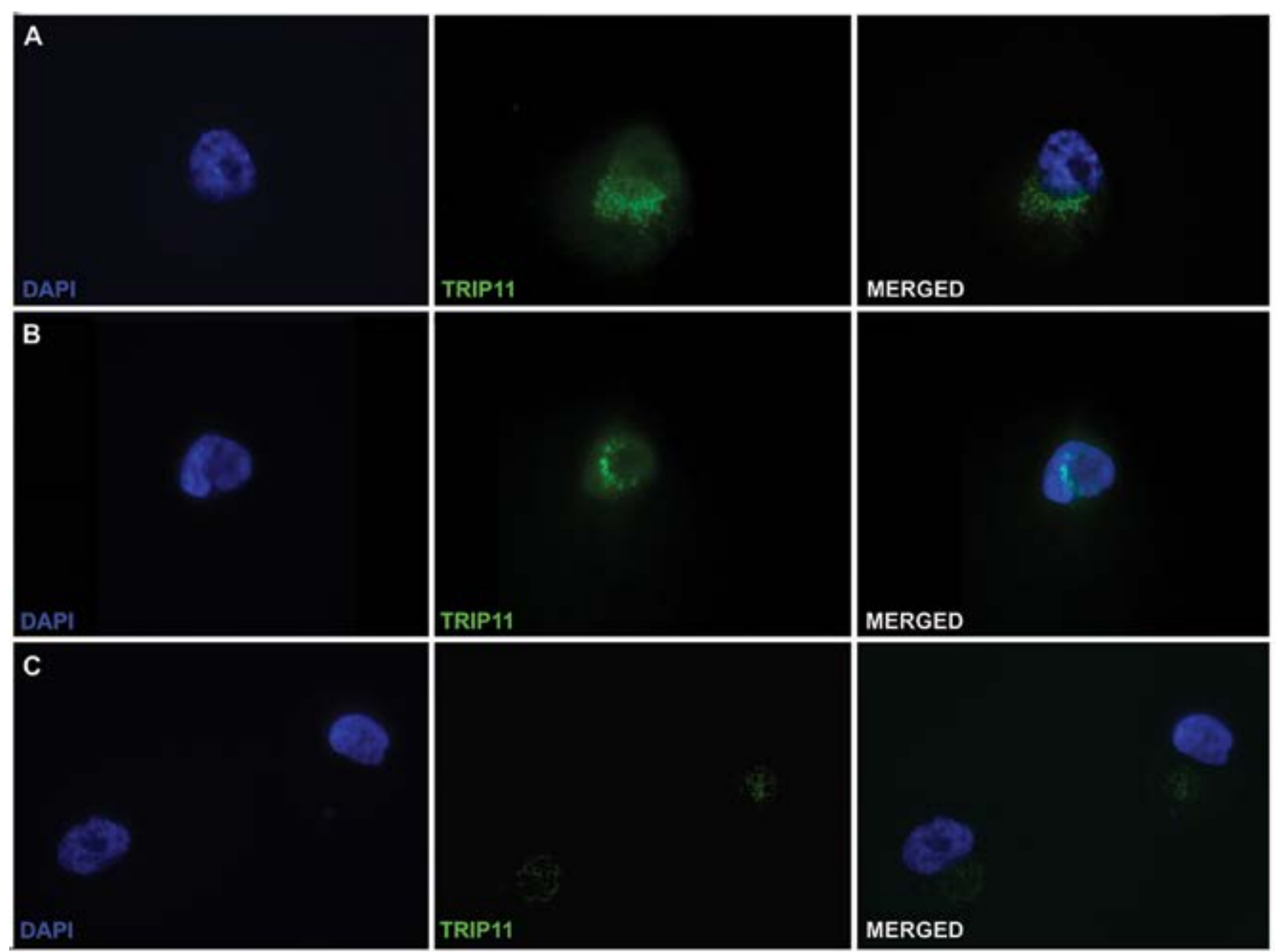

Figure 1. Wortmannin prevents T3-induced nuclear localisation of TRIP11. A. Cells cultured without T3 - TRIP11 localises in cytoplasm (probably in Golgi apparatus); B. Cells treated with 100 nM T3 - TRIP11 localises in nucleus; C. Cells pre-treated with $100 \mathrm{nM}$ wortmannin and cultured in the presence of $100 \mathrm{nM}$ T3 - TRIP11 localises in cytoplasm (probably in Golgi apparatus); Images of Caki-2 cells were taken with a Zeiss Axio Observer D1 microscope equipped with 100X oil-immersion objective, stained with DAPI (first column), anti-TRIP11 antibody (second column), and merged (third column)

Rycina 1. Blokowanie indukowanej przez T3 zmiany lokalizacji TRIP11 przez wortmaninę. A. Komórki hodowane bez T3 — TRIP11 jest zlokalizowany w cytoplazmie (prawdopodobnie w aparacie Golgiego); B. Komórki traktowane 100nM T3 — TRIP11 jest zlokalizowany $w$ jądrze komórkowym; C. Komórki preinkubowane z 100nM wortmanina i hodowane w obecności 100nM T3 — TRIP11 jest zlokalizowany w cytoplazmie (prawdopodobnie w aparacie Golgiego). Zdjęcia komórek linii Caki-2 wykonano z wykorzystaniem mikroskopu Zeiss Axio Observer D1 wyposażonego w obiektyw immersyjny o powiększeniu 100x, barwione DAPI (pierwsza kolumna), znakowane przeciwciałem anti-TRIP11 (druga kolumna). Scalone zdjęcia sa pokazane w trzeciej kolumnie

\section{Disturbed expression of TRIP11 and ARNT correlates with RCC tumour grade}

Next, to check the association of TRIP11 and ARNT with tumour pathology, we analysed their expression in different RCC tumour grades. To ensure the appropriate number of samples for statistical analysis, we took advantage of the publically available data of The Cancer Genome Atlas network (TCGA) [19]. The expressions of TRIP11 and ARNT statistically significantly decreased with increase of tumour grade (Fig. 5). In agreement with previous studies, expressions of THRA and THRB were also lowered in higher tumour grades (Fig. 5).

\section{Disturbed expression of genes involved in T3 signalling correlates with poor survival of RCC patients}

Finally, we tested the associations between the expression of $\mathrm{T} 3$ signalling genes and survival of RCC patients (Fig. 6). Low expressions of TRIP11, THRA, and THRB independently correlated with poor survival of RCC patients $\left(\mathrm{HR}=1.8, \mathrm{p}=5.1 \times 10^{-4} ; \mathrm{HR}=2.0, \mathrm{p}=1.6 \times\right.$ $10^{-5} ; \mathrm{HR}=1.8 ; \mathrm{p}=2.1 \times 10^{-4}$, respectively). When the integrated signature of expression of all three genes was tested, the effect on patient survival was even stronger $\left(\mathrm{HR}=2.6, \mathrm{p}=1.6 \times 10^{-8}\right)$. 

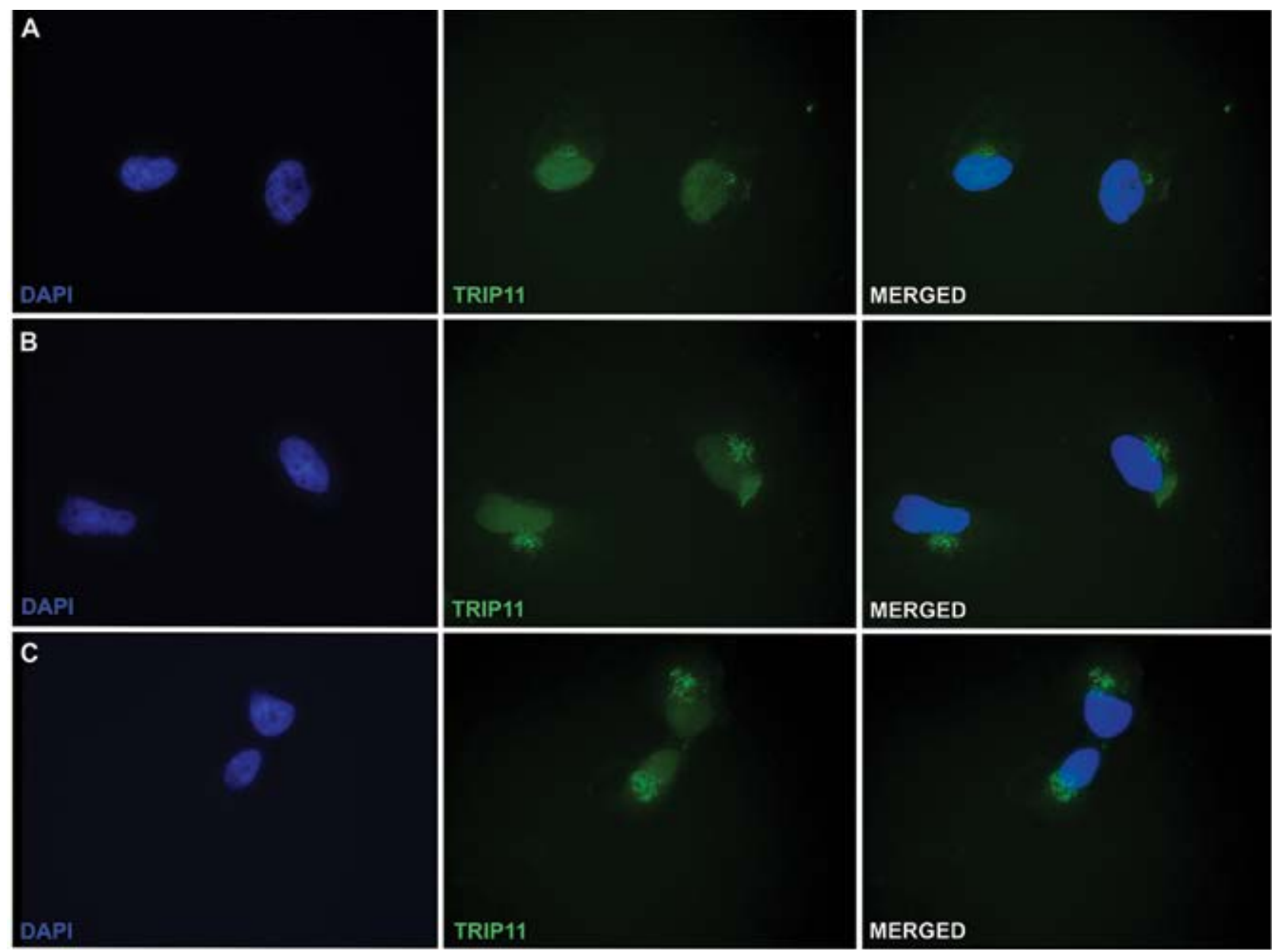

Figure 2. Triiodothyronine-agarose treatment has no influence on TRIP11 localisation. A. Cells treated with low T3-agarose concentration (100 nM) - TRIP11 localises in cytoplasm (probably in Golgi apparatus); B. Cells treated with medium T3-agarose concentration (200 nM) - TRIP11 localises in cytoplasm (probably in Golgi apparatus); C. Cells treated with high T3-agarose concentration (600 nM) - TRIP11 localises in cytoplasm (probably in Golgi apparatus). Similar results were obtained for $30 \mathrm{nM}, 200 \mathrm{nM}$ and $1800 \mathrm{nM}$ T3-agarose concentrations. Images of Caki-2 cells were taken using a Zeiss Axio Observer D1 microscope equipped with 100X oilimmersion objective, stained with DAPI (first column), anti-TRIP11 antibody (second column), and merged (third column)

Rycina 2. Brak wptywu T3 sprzężonego z agaroza na lokalizację TRIP11. A. Komórki traktowane niskim stężeniem T3-agarozy (100nM) — TRIP11 jest zlokalizowany w cytoplazmie (prawdopodobnie w aparacie Golgiego); B. Komórki traktowane średnim stężeniem T3-agarozy (200nM) - TRIP11 jest zlokalizowany w cytoplazmie (prawdopodobnie w aparacie Golgiego); C. Komórki traktowane wysokim stężeniem T3-agarozy (200nM) — TRIP11 jest zlokalizowany w cytoplazmie (prawdopodobnie w aparacie Golgiego). Identyczne wyniki osiagnięto dla T3-agarozy w stężeniach 30nM, 200nM i 1800 nM. Zdjęcia komórek linii Caki-2 wykonano z wykorzystaniem mikroskopu Zeiss Axio Observer D1 wyposażonego w obiektyw immersyjny o powiększeniu 100x, barwione DAPI (pierwsza kolumna), znakowane przeciwciatem anti-TRIP11 (druga kolumna). Scalone zdjęcia sa pokazane w trzeciej kolumnie

\section{Discussion}

In this study, we showed for the first time that T3 regulates subcellular localisation of TRIP11 by a mechanism involving PI3K kinase. We also revealed that renal tumours are characterised by changes in coregulatory network of T3 and hypoxia signalling pathway and showed that altered expression of genes involved in thyroid hormone signalling correlates with poor survival of renal cancer patients.

FURIN, GLUT1, and VEGFA are genes actively contributing to carcinogenic process. FURIN is a proprotein convertase that activates precursor proteins by amino acid sequence-specific cleavage. The expression of FURIN is often disturbed in cancers and contributes to activation of cancer-promoting proteins such as TGF- $\beta 1$ $[24,25]$. GLUT1 is a glucose transporter commonly upregulated in cancers, which facilitates enhanced glucose uptake and the pro-proliferative metabolic switch in tumour cells [26]. VEGFA is an important growth factor enabling activation of angiogenesis in solid tumours [27-32]. Remarkably, all of these three genes are commonly regulated by thyroid hormone signalling and hypoxia [12-14, 23, 24]. In agreement with this, in nontumorous kidney control samples we observed strong correlations between the expression of genes involved in 


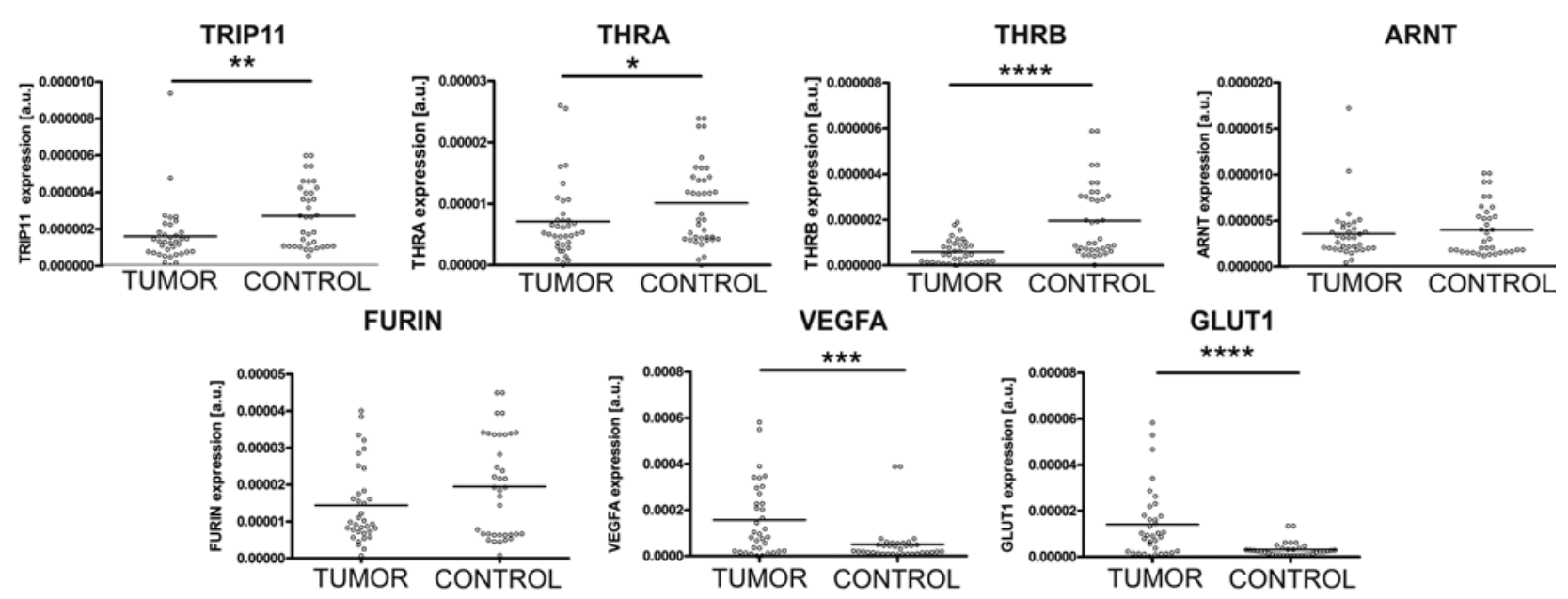

Figure 3. The expression of TRIP11 and TRIP11-related genes in renal cancer. The results of qPCR analysis performed in RCC tumours $(n=36)$ and paired-matched controls $(n=36)$. Statistical analysis was performed using Wilcoxon matched-pairs signed rank test ${ }^{*} p<0.05,{ }^{* *} p<0.01,{ }^{* * *} p<0.001,{ }^{* * * *} p<0.0001$

Rycina 3. Ekspresja TRIP11 i genów związanych z TRIP11 w raku nerki. Wyniki analizy qPCR przeprowadzonej w guzach RCC $(n=36)$ i sparowanych tkankach nienowotworowych $(n=36)$. Analizę statystyczna przeprowadzono z wykorzystaniem testu Wilcoxona dla par obserwacji ${ }^{*} p<0,05,{ }^{* *} p<0,01,{ }^{* * *} p<0,001,{ }^{* * *} p<0,0001$

CONTROL correlation coefficients

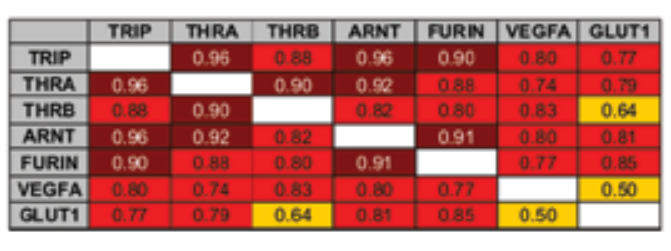

$p$ values

\begin{tabular}{|c|c|c|c|c|c|c|c|}
\hline & TRIP & THRA & THRB & ARNT & FURIN & VEGFA & GLUT1 \\
\hline TRIP & & $6.5 E-20$ & $2.6 E-12$ & $3.8 E-21$ & $7.4 E-14$ & $7.8 E-09$ & $3.7 E-08$ \\
\hline THRA & $6.5 E-20$ & & $9.2 E-14$ & $3.7 E-15$ & $8.8 E-13$ & $4.0 E-07$ & $1.3 E-08$ \\
\hline THRB & $2.6 E-12$ & $9.2 E-14$ & & $8.2 E-10$ & $4.9 E-09$ & $8.1 E-10$ & $3.0 E-05$ \\
\hline ARNT & $3.9 E-21$ & $3.7 E-15$ & $8.2 E-10$ & & $1.1 E-14$ & $8.4 E-09$ & $1.5 E-09$ \\
\hline FURIN & $7.4 E-14$ & $8.8 E-13$ & $4.9 E-09$ & $1.1 E-14$ & & $8.6 E-08$ & $5.8 E-11$ \\
\hline VEGFA & $7.8 E-09$ & $4.0 E-07$ & $8.1 E-10$ & $8.4 E-09$ & $8.6 E-08$ & & $2.2 E-03$ \\
\hline GLUT1 & $3.7 E-08$ & $1.3 E-08$ & $3.0 E-05$ & $1.5 E-09$ & $5.8 E-11$ & $2.2 E-03$ & \\
\hline
\end{tabular}

TUMOR correlation coefficients

\begin{tabular}{|l|c|c|c|c|c|c|c|}
\hline & TRIP & THRA & THRB & ARNT & FUREN & VEGFA & GLUT1 \\
\hline TRIP & & 0.90 & 0.79 & 0.81 & 0.80 & 0.30 & 0.17 \\
\hline THRA & 0.90 & & 0.83 & 0.75 & 0.74 & 0.35 & 0.20 \\
\hline THRB & 0.79 & 0.83 & & 0.54 & 0.57 & 0.09 & -0.01 \\
\hline ARNT & 0.81 & 0.75 & 0.54 & & 0.79 & 0.41 & 0.40 \\
\hline FURIN & 0.80 & 0.74 & 0.57 & 0.79 & & 0.29 & 0.43 \\
\hline VEGFA & 0.30 & 0.35 & 0.09 & 0.41 & 0.29 & & 0.71 \\
\hline GLUT1 & 0.17 & 0.20 & -0.01 & 0.40 & 0.43 & 0.71 & \\
\hline
\end{tabular}

$\mathrm{p}$ values

\begin{tabular}{|c|c|c|c|c|c|c|c|}
\hline & TRIP & THRA & THRB & ARNT & FURIN & VEGFA & GLUT1 \\
\hline TRIP & & $3.4 E-13$ & $1.3 \mathrm{E}-08$ & $4.8 \mathrm{E}-09$ & $5.9 \mathrm{E}-09$ & $7.8 \mathrm{E}-02$ & $3.3 \mathrm{E}-01$ \\
\hline THRA & $3.4 \mathrm{E}-13$ & & $1.0 \mathrm{E}-09$ & $2.4 \mathrm{E}-07$ & $4.2 \mathrm{E}-07$ & $4.0 \mathrm{E}-02$ & $2.4 \mathrm{E}-01$ \\
\hline THRB & $1.3 \mathrm{E}-08$ & $1.0 \mathrm{E}-09$ & & $7.5 \mathrm{E}-04$ & $3.8 \mathrm{E}-04$ & $6.0 \mathrm{E}-01$ & $9.7 \mathrm{E}-01$ \\
\hline ARNT & $4.8 \mathrm{E}-09$ & $2.4 \mathrm{E}-07$ & $7.5 \mathrm{E}-04$ & & $1.7 \mathrm{E}-08$ & $1.3 \mathrm{E}-02$ & $1.9 \mathrm{E}-02$ \\
\hline FURIN & $5.9 \mathrm{E}-09$ & $4.2 \mathrm{E}-07$ & $3.8 \mathrm{E}-04$ & $1.7 \mathrm{E}-08$ & & $8.7 \mathrm{~T}-02$ & $1.0 \mathrm{E}-02$ \\
\hline VEGFA & $7.8 \mathrm{E}-02$ & $4.0 \mathrm{E}-02$ & $6.0 \mathrm{E}-01$ & $1.3 \mathrm{E}-02$ & $8.7 \mathrm{E}-02$ & & $2.1 \mathrm{E}-06$ \\
\hline GLUT1 & $3.3 \mathrm{E}-01$ & $2.4 \mathrm{E}-01$ & $9.7 \mathrm{E}-01$ & $1.9 \mathrm{E}-02$ & $1.0 \mathrm{E}-02$ & $2.1 \mathrm{E}-06$ & \\
\hline
\end{tabular}
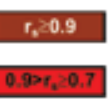
$0.7>r_{y}>0.5$ $r, \propto 0.5$

Figure 4. Correlation of gene expression in tumour and control samples. Correlation matrix for controls (left) and tumours (right). The tables show Spearman's rank correlation coefficient values for gene expressions analysed in 36 RCC tumours and 36 paired-matched controls. Dark red: $r_{s} \geq 0.9$, red: $0.9>r_{s} \geq 0.7$, orange: $0.7>r_{s} \geq 0.5$. The $p$ values are presented in lower tables (yellow $\left.p \leq 0.05\right)$. The plots showing correlations between analysed genes are presented in Supplementary Figure 2

Rycina 4. Korelacja ekspresji genów w tkankach nowotworowych i nienowotworowych. Macierz korelacji dla tkanek kontrolnych (po lewej) i guzów (po prawej). Tabele pokazuja wspótczynnik korelacji rang Spearmana dla ekspresji genów analizowanych w 36 guzach RCC $i$ parowanych tkankach kontrolnych. Legenda: kolor ciemnoczerwony: $r_{s} \geq 0,9$, czerwony: 0,9> $r_{s} \geq 0,7$, pomarańczowy: 0,7 > $r_{s} \geq 0,5$. Dolne tabele prezentują wartości $p$ (żótty $p \leq 0,05$ ). Wykresy pokazujące korelację pomiędzy analizowanymi genami znajduja się na dodatkowej rycinie 2

hypoxia and T3 signalling. In contrast, these correlations were weakened or even lost in RCC tumours (Fig. 4). This might suggest that in tumour cells the control of some genes by T3 signalling is lost. Indeed, RCC tumours are characterised by decreased expression of THRs [2-4]. Furthermore, it was shown that THRB may counteract PI3K activation in cancer cells, leading to attenuation of VEGF activation [13]. Thus, the loss of THRB in
RCC tumours might further contribute to induction of VEGF expression. Moreover, T3 concentrations in RCC tumours are also significantly suppressed [3]. This could imply that T3-dependent nuclear targeting of TRIP11 might be impaired in RCC tumours and in turn disturb the co-activator functions of TRIP11. To verify this hypothesis, the possible changes in subcellular localisation of TRIP11 in RCC tumours should be analysed. 

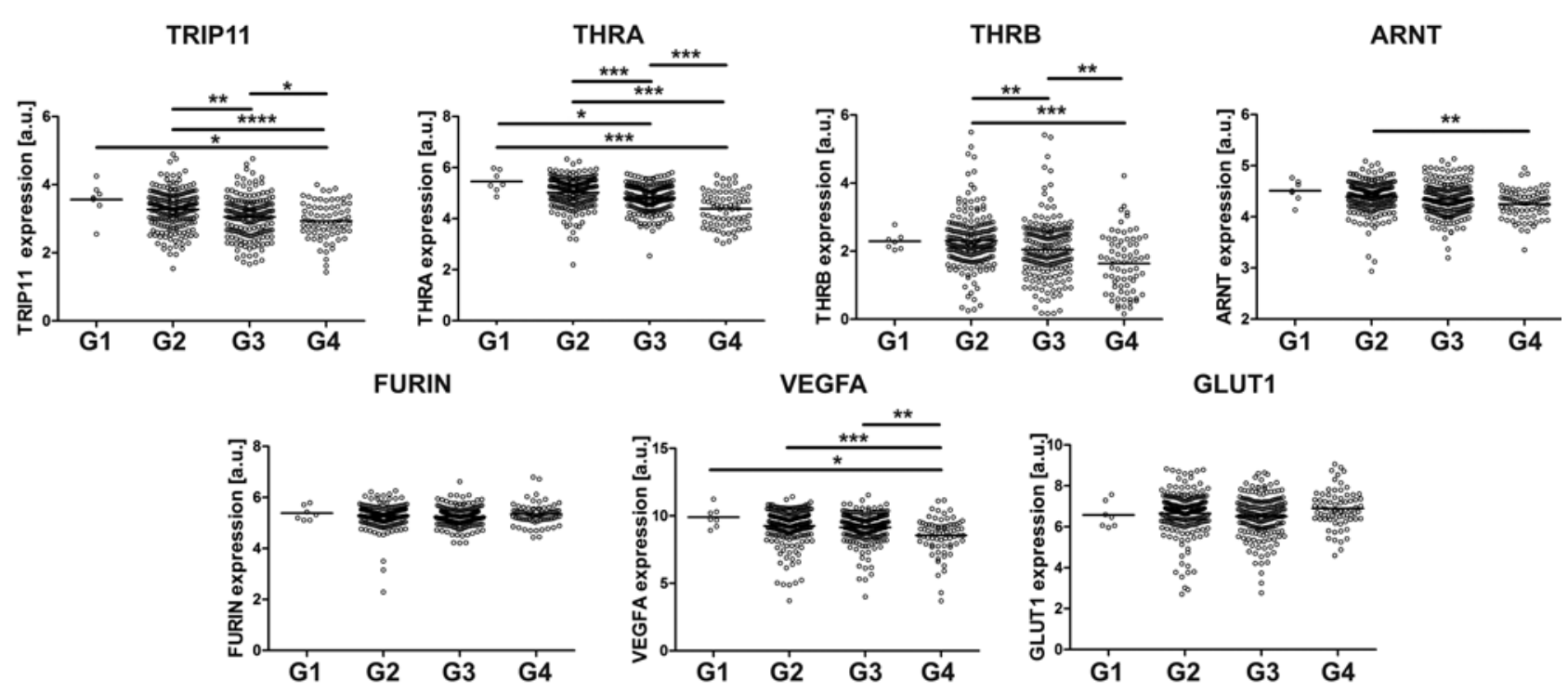

Figure 5. Changes in gene expression in renal tumours of different Fuhrman grades. The plots show expression of genes in G1 $(N=7), G 2(N=199), G 3(N=185)$, and $G 4(N=73)$ tumour grades. Data obtained from The Cancer Genome Atlas (TCGA, http://cancergenome.nih.gov) [19]. Statistical analysis was performed using one-way ANOVA with Bonferroni multiple comparisons post-test or Kruskal-Wallis test with Dunn's Multiple Comparison Test

${ }^{*} \mathbf{p}<0.05,{ }^{* *} p<0.01,{ }^{* *} p<0.001$

Rycina 5. Zmiany ekspresji genów w guzach nerki o różnym stopniu zaawansowania (klasyfikacja Fuhrmana). Wykresy pokazuja ekspresje genów w guzach G1 $(N=7), G 2(N=199), G 3(N=185)$ i G4 $(N=73)$. Dane pozyskano z The Cancer Genome Atlas (TCGA, http://cancergenome.nih.gov) [19]. Analizę statystycznq przeprowadzono z wykorzystaniem jednoczynnikowej analizy wariancji z testem post-hoc Bonferroniego lub testu Kruskal-Wallisa z testem post-hoc Dunna

${ }^{*} \mathbf{p}<0,05,{ }^{* *} p<0,01,{ }^{* *} p<0,001$

Depletion of TRIP11 from mouse embryos leads to fragmentation of Golgi apparatus in kidney cells, thus interfering with secretory trafficking [33]. It was also suggested that TRIP11 may play a specific role in secretion of extracellular matrix proteins [34]. Remarkably, disturbances in expression and secretion of ECM proteins contribute to the progression of renal and other cancers $[17,35,36]$. Thus, disturbed expression of TRIP11 might also contribute to alterations in ECM of renal tumours. This possibility should be also experimentally evaluated. When confirmed, this could at least partially explain the mechanism by which decreased TRIP11 expression may contribute to the lower survival of RCC patients.

Finally, the possible protective role of $\mathrm{T} 3$ signalling in cancer is in agreement with the well-known tumour suppressive roles of THRB [13,37]. The results of our study fit this model well because decreased expression of genes involved in T3 signalling correlated with poor survival of RCC patients (Fig. 6).

The significance of our results might expand beyond the molecular basis of carcinogenesis. TRIP11 is indispensable for proper development of bone, and its loss in mice leads to lethal skeletal dysplasia [33]. Furthermore, patients with achondrogenesis type 1A, a neonatal, lethal form of skeletal dysplasia, bear inac- tivating mutations in the TRIP11 gene [33]. It is known that thyroid hormones are indispensable for proper development and that mutation in THRs or changes in intracellular T3 levels lead to disturbances in bone formation [38]. These effects are explained mainly by loss of T3-dependent effects on gene expression. However, it may be hypothesised that spatio-temporal intracellular changes in T3 may also contribute to the process of bone formation by affecting TRIP11 localisation. This hypothesis should be verified by future studies.

\section{Conclusions}

To sum up, this study revealed the PI3K-involving mechanism by which $\mathrm{T} 3$ regulates intranuclear trafficking of TRIP11. We also demonstrated changes in the network of genes involved in hypoxia and thyroid hormone signalling, possibly indicating the loss of T3 control on expression of targets involved in the regulation of tumour progression. The study shows for the first time that disturbed expression of T3 signalling pathway genes correlates with progression of RCC. The specific mechanisms by which altered expression of genes involved in T3 signalling contribute to poor survival of RCC patients require further investigation. 
A

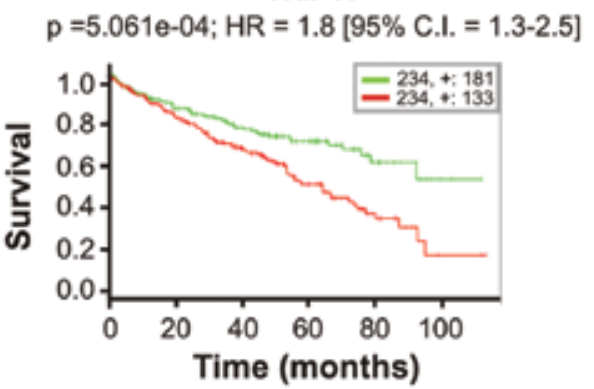

$R=1.8[95 \%$ C.I. $=1.3-2.6]$
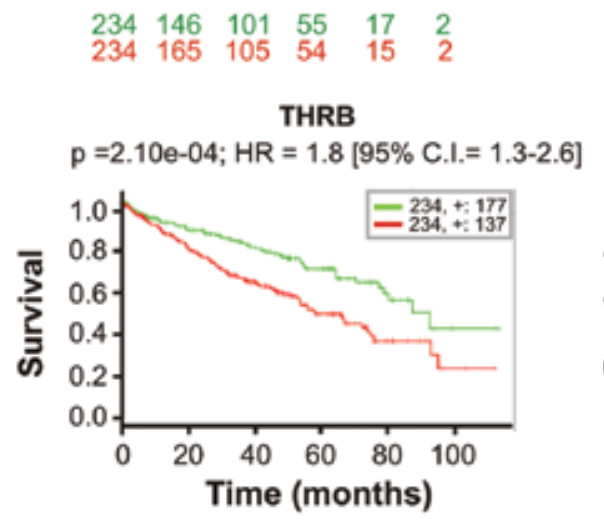

THRA

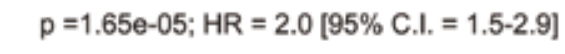

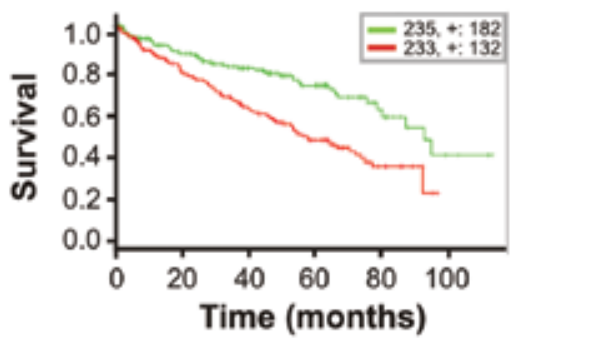

$\begin{array}{llllll}235 & 162 & 104 & 57 & 18 & 4\end{array}$

$\begin{array}{llllll}233 & 149 & 102 & 52 & 14 & 0\end{array}$

TRIP11 THRA THRB

$p=1.631 \mathrm{e}-08 ; \mathrm{HR}=2.6[95 \% \mathrm{C} . \mathrm{I} .=1.8-3.7]$

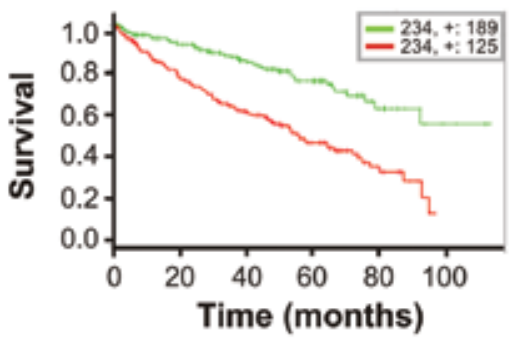

$\begin{array}{llllll}234 & 161 & 106 & 61 & 18 & 4\end{array}$ $\begin{array}{llllll}234 & 150 & 100 & 48 & 14 & 0\end{array}$

B HIGH RISK LOW RISK
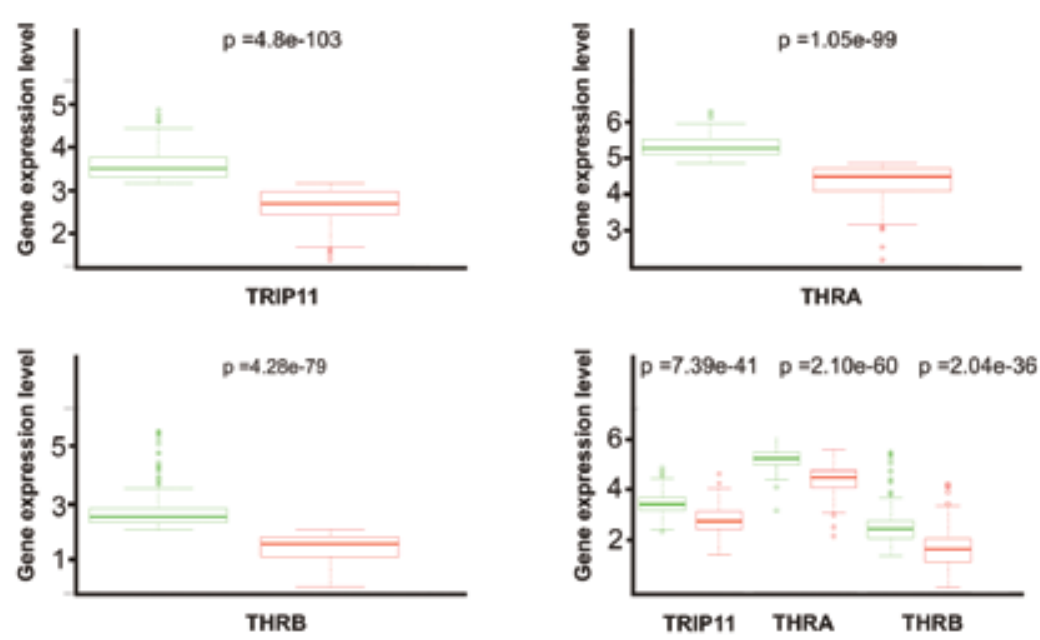

Figure 6. The expression of TRIP11, THRA, and THRB correlates with RCC patients' survival rate. A. The graphs show results of Kaplan-Meier analysis of patients' survival for TRIP11, THRA, and THRB analysed separately and as a panel of genes (TRIP11, THRA, THRB) in a cohort of 468 patients. The data was retrieved from TCGA and the analysis was performed using SurvExpress. The red and green lines depict patients with high and low risk, respectively. The numbers of patients in each group are shown below the graphs. Censored observations are shown with + . Log-rank $p$ values, hazard ratio (HR), and confidence intervals (C.I.) are shown above each graph; B. The expression of genes stratified by risk groups. The data was retrieved from TCGA and the analysis was performed using SurvExpress; $t$-test was used to compute $p$ values. $P<0.05$ was considered statistically significant. $P$ values are shown above box plots for each gene. Green - expression in low-risk group. Red - expression in high-risk group. Note that the scales are different

Rycina 6. Ekspresja TRIP11, THRA i THRB koreluje z czasem przeżycia pacjentów z RCC. A Wykresy pokazują wyniki analizy przeżycia Kaplana-Meiera pacjentów z RCC dla TRIP11, THRA, THRB analizowanych oddzielnie i jako panel genów (TRIP11, THRA, THRB) na danych transkryptomicznych pochodzących od 468 chorych. Dane pozyskane zostaty z ogólnodostępnej bazy konsorcjum TCGA, analizę prowadzono z wykorzystaniem narzędzia SurvExpress. Czerwone i zielone linie przedstawiają pacjentów z, odpowiednio, wysokim i niskim ryzykiem śmierci. Liczba pacjentów w każdej grupie pokazana jest pod wykresem. Cenzurowane obserwacje sq pokazane za pomoca znaku +. Nad każdym wykresem pokazane sq wartości log-rank p, ryzyko względne (HR) i przedziaty ufności (C.I.); B. Analiza poziomu ekspresji genów z podziatem na grupy ryzyka. Dane pozyskano z TCGA ianalizowanoz wykorzystaniem narzędzia SurvExpress; do obliczenia istotności statystycznej wykorzystywano test-t; $p<0,05$ uznawano za istotne statystycznie. Kolor zielony - ekspresja genu w grupie niskiego ryzyka. Kolor czerwony — ekspresja genu w grupie wysokiego ryzyka. Uwaga — skale są różne dla poszczególnych wykresów 
TRIP11

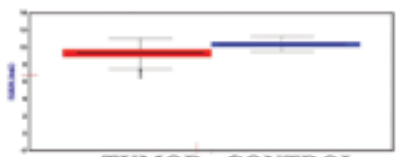

TUMOR CONTROL
THRA

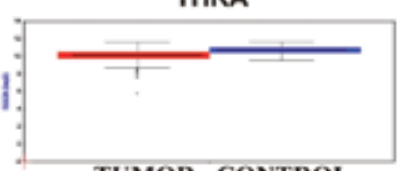

TUMOR CONTROL

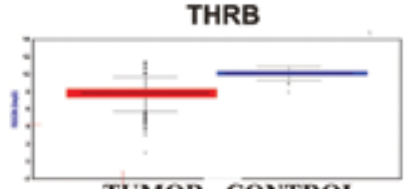

TUMOR CONTROL

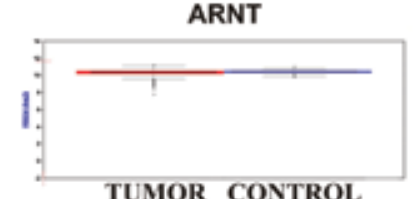

TUMOR CONTROL

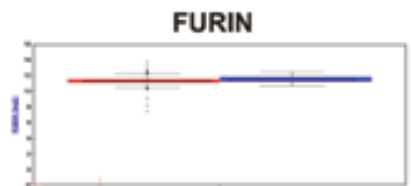

TUMOR CONTROL

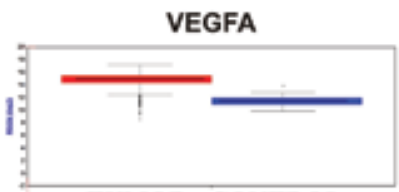

TUMOR CONTROL

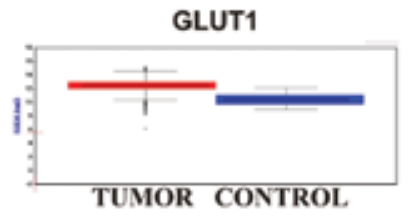

Supplementary figure 1. Validation of gene expression analysis on independent cohort of RCC patients. The plots show median expression of genes generated using Firebrowse tool (firebrowse.org), accessed on 16.12.2016, using clear cell renal cell carcinoma (KIRC) data of The Cancer Genome Atlas (TCGA, http://cancergenome.nih.gov, [19]) consortium. The number of tumour samples available for analysis was $n=534$, and the number of non-tumorous control samples was $n=72$ for each analysed gene

Rycina dodatkowa 1. Walidacja poziomu ekspresji genów na niezależnej kohorcie chorych z RCC. Wykresy pokazujące medianę ekspresji genów zostały wygenerowane przez narzędzie Firebrowse (firebrowse.org), dnia 16.12.2016, z wykorzystaniem bazy danych dla RCC (KIRC) $z$ The Cancer Genome Atlas (TCGA, http://cancergenome.nih.gov, [19]). Dla każdego analizowanego genu dostępne byty dane dla 534 tkanek nowotworowych i 72 tkanek nienowotworowych
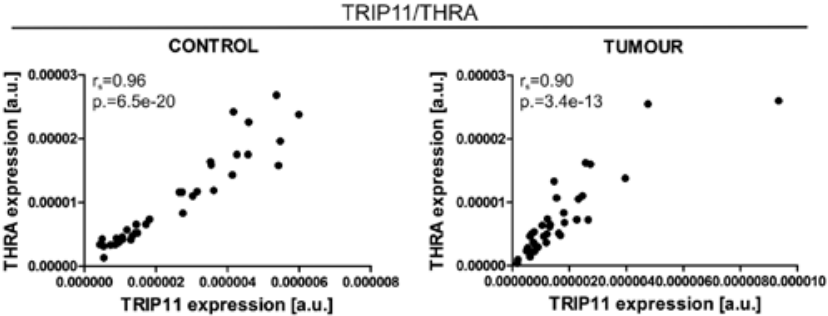

TRIP11/ARNT
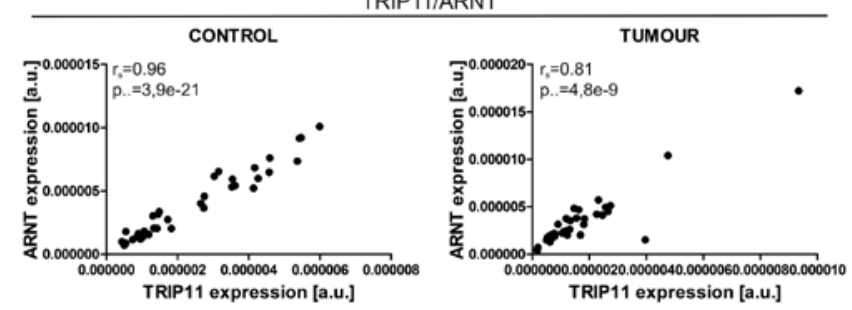

THRATHRB
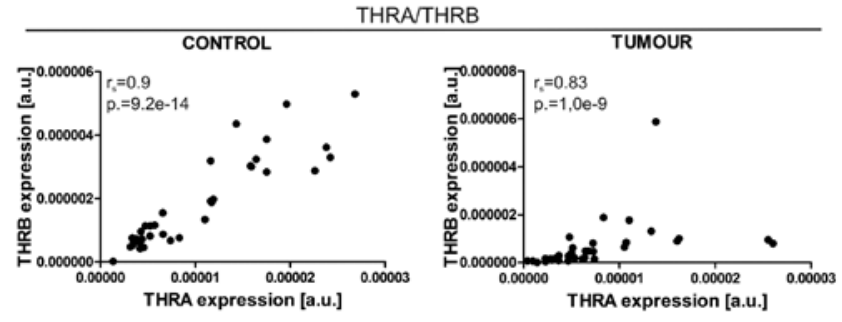

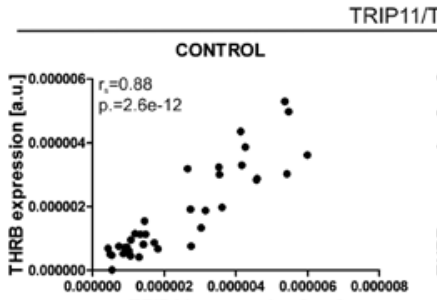

TRIP11 expression [a.u.]
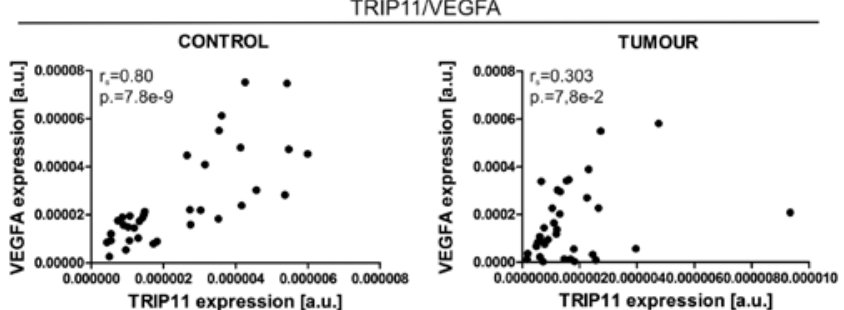

THRAFURIN
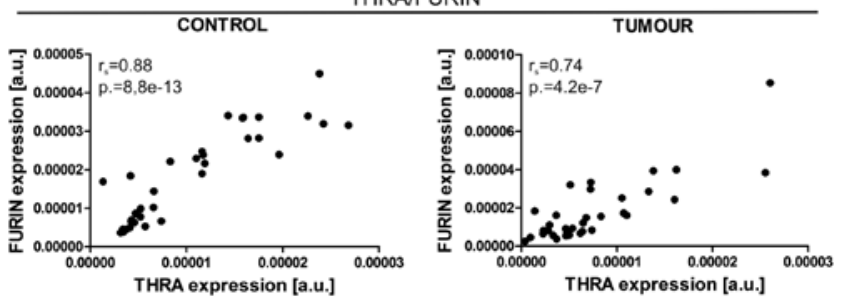

Supplementary figure 2. Correlation of gene expression in tumour and control samples. The plots show correlation between expression of TRIP11, THRA, THRB, ARNT and THRA, THRB, FURIN, VEGFA, and GLUT1 in control $(n=36)$ and tumour tissues $(n=36)$ $r_{s}=$ Spearman's rank correlation coefficient; $p<0.05$ was considered statistically significant

Rycina dodatkowa 2. Korelacja poziomu ekspresji genów w tkankach nowotworowych i nienowotworowych. Wykresy pokazuja korelacje pomiędzy ekspresja TRIP11, THRA, THRB, ARNT i THRA, THRB, FURIN, VEGFA, GLUT1 w tkankach kontrolnych $(n=36) i \operatorname{guzach}(n=36)$

$r_{s}$ - wspótczynnik korelacji rang Spearmana, $p<0,05$ uznano za istotne statystycznie 

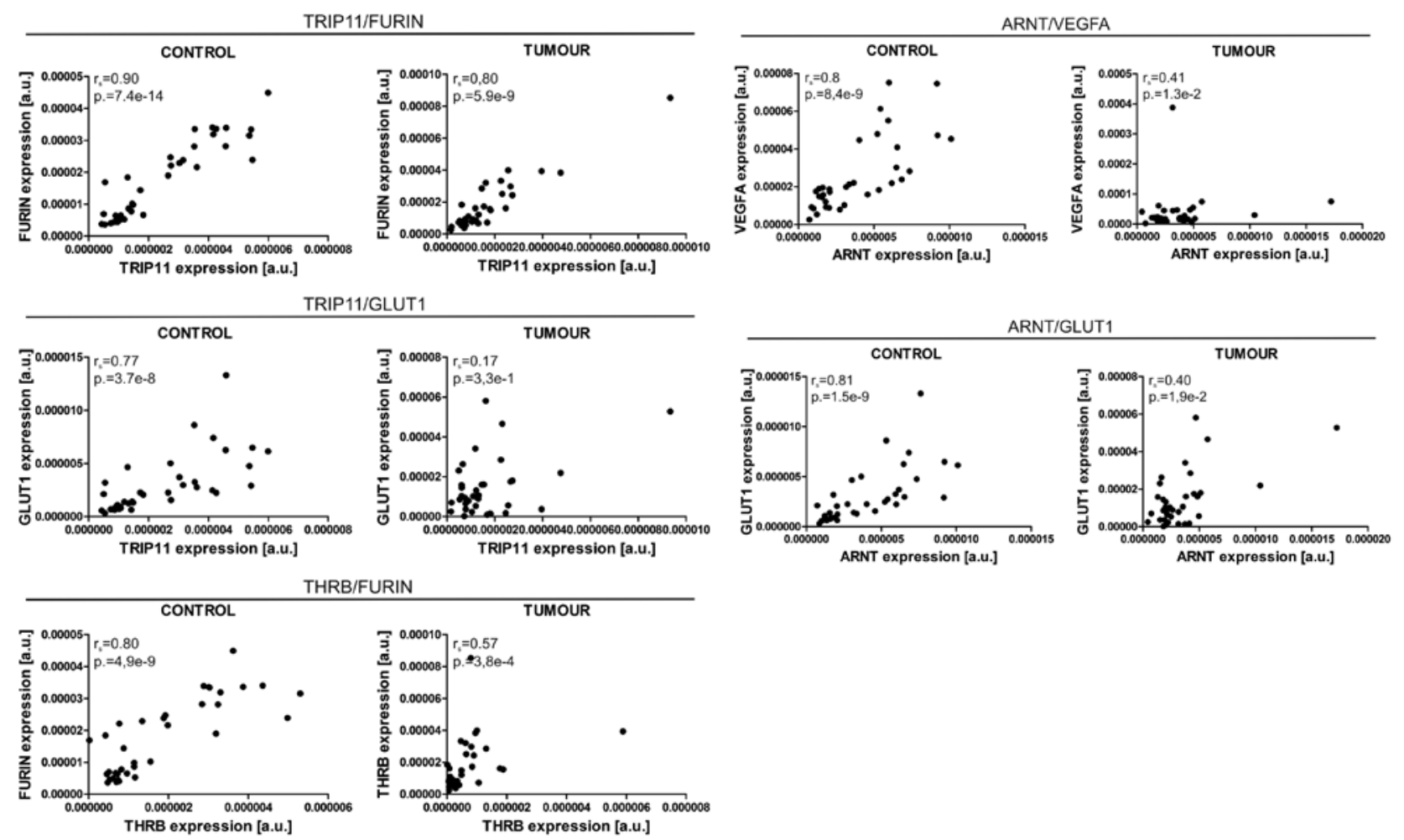

Supplementary figure $2 \mathrm{~cd}$. Correlation of gene expression in tumour and control samples. The plots show correlation between expression of TRIP11, THRA, THRB, ARNT and THRA, THRB, FURIN, VEGFA, and GLUT1 in control $(n=36)$ and tumour tissues $(n=36)$ $r_{s}=$ Spearman's rank correlation coefficient; $p<0.05$ was considered statistically significant

Rycina dodatkowa 2. Korelacja poziomu ekspresji genów w tkankach nowotworowych i nienowotworowych. Wykresy pokazuja korelacje pomiędzy ekspresja TRIP11, THRA, THRB, ARNT i THRA, THRB, FURIN, VEGFA, GLUT1 w tkankach kontrolnych (n =36) $i$ guzach $(n=36)$

$r_{s}$ - wspótczynnik korelacji rang Spearmana; $p<0,05$ uznano za istotne statystycznie

\section{Founding Sources}

The study was supported by Centre of Postgraduate Medical Education grants (501-1-25-03-10, 501-1-25-01-11, 501-1-25-01-12) and National Science Centre, Poland (2014/13/B/NZ5/00283).

\section{References}

1. Szymański Ł, Matak D, Bartnik E, et al. Thyroid Hormones as Renal Cell Cancer Regulators. J Signal Transduct. 2016; 2016: 1362407, doi: 10.1155/2016/1362407, indexed in Pubmed: 27034829.

2. Wojcicka A, Piekielko-Witkowska A, Kedzierska H, et al. Epigenetic regulation of thyroid hormone receptor beta in renal cancer. PLoS One. 2014; 9(5): e97624, doi: 10.1371/journal.pone.0097624, indexed in Pubmed: 24849932

3. Master A, Wójcicka A, Piekiełko-Witkowska A, et al. Untranslated regions of thyroid hormone receptor beta $1 \mathrm{mRNA}$ are impaired in human clear cell renal cell carcinoma. Biochim Biophys Acta. 2010; 1802(11): 995-1005, doi: 10.1016/j.bbadis.2010.07.025, indexed in Pubmed: 20691260.

4. Puzianowska-Kuznicka M, Nauman A, Madej A, et al. Expression of thyroid hormone receptors is disturbed in human renal clear cell carcinoma. Cancer Lett. 2000; 155(2): 145-152, doi: 10.1016/s0304-3835(00)00416-x, indexed in Pubmed: 10822129.

5. Ríos RM, Sanchís A, Tassin AM, et al. GMAP-210 recruits gamma-tubulin complexes to cis-Golgi membranes and is required for Golgi ribbon formation. Cell. 2004; 118(3): 323-335, doi: 10.1016/j.cell.2004.07.012, indexed in Pubmed: 15294158.

6. Chang KH, Chen Y, Chen TT, et al. A thyroid hormone receptor coactivator negatively regulated by the retinoblastoma protein. Proc Natl Acad Sci U S A. 1997; 94(17): 9040-9045, doi: 10.1073/pnas.94.17.9040, indexed in Pubmed: 9256431.
7. Beischlag TV, Taylor RT, Rose DW, et al. Recruitment of thyroid hormone receptor/retinoblastoma-interacting protein 230 by the aryl hydrocarbon receptor nuclear translocator is required for the transcriptional response to both dioxin and hypoxia. J Biol Chem. 2004; 279(52): 54620-54628, doi: 10.1074/jbc.M410456200, indexed in Pubmed: 15485806.

8. Labrecque MP, Takhar MK, Jagdeo JM, et al. A TRIP230-retinoblastoma protein complex regulates hypoxia-inducible factor- $1 \alpha$-mediated transcription and cancer cell invasion. PLoS One. 2014; 9(6): e99214, doi: 10.1371/journal.pone.0099214, indexed in Pubmed: 24919196.

9. Rankin EB, Giaccia AJ. Hypoxic control of metastasis. Science. 2016; 352(6282): 175-180, doi: 10.1126/science.aaf4405, indexed in Pubmed: 27124451.

10. Perra A, Plateroti M, Columbano A. T3/TRs axis in hepatocellular carcinoma: new concepts for an old pair. Endocr Relat Cancer. 2016; 23(8): R353-R369, doi: 10.1530/ERC-16-0152, indexed in Pubmed: 27353037.

11. Moeller LC, Cao X, Dumitrescu AM, et al. Thyroid hormone mediated changes in gene expression can be initiated by cytosolic action of the thyroid hormone receptor beta through the phosphatidylinositol 3-kinase pathway. Nucl Recept Signal. 2006; 4: e020, indexed in Pubmed: 16862226.

12. Zimna A, Kurpisz M. Hypoxia-Inducible Factor-1 in Physiological and Pathophysiological Angiogenesis: Applications and Therapies. Biomed Res Int. 2015; 2015: 549412, doi: 10.1155/2015/549412, indexed in Pubmed: 26146622.

13. Kim WGu, Zhao Li, Kim DW, et al. Inhibition of tumorigenesis by the thyroid hormone receptor $\beta$ in xenograft models. Thyroid. 2014; 24(2): 260-269, doi: 10.1089/thy.2013.0054, indexed in Pubmed: 23731250.

14. Zhang L, Cooper-Kuhn CM, Nannmark U, et al. Stimulatory effects of thyroid hormone on brain angiogenesis in vivo and in vitro. J Cereb Blood Flow Metab. 2010; 30(2): 323-335, doi: 10.1038/jcbfm.2009.216, indexed in Pubmed: 19861975.

15. Moeller LC, Führer D. Thyroid hormone, thyroid hormone receptors, and cancer: a clinical perspective. Endocr Relat Cancer. 2013; 20(2): R19-R29, doi: 10.1530/ERC-12-0219, indexed in Pubmed: 23319493. 
16. Chen Y, Chen PL, Chen CF, et al. Thyroid hormone, T3-dependent phosphorylation and translocation of Trip230 from the Golgi complex to the nucleus. Proc Natl Acad Sci U S A. 1999; 96(8): 4443-4448, indexed in Pubmed: 10200281.

17. Boguslawska J, Kedzierska H, Poplawski P, et al. Expression of Genes Involved in Cellular Adhesion and Extracellular Matrix Remodeling Correlates with Poor Survival of Patients with Renal Cancer. J Urol. 2016; 195(6): 1892-1902, doi: 10.1016/j.juro.2015.11.050, indexed in Pubmed: 26631499.

18. Aguirre-Gamboa R, Gomez-Rueda H, Martínez-Ledesma E, et al. SurvExpress: an online biomarker validation tool and database for cancer gene expression data using survival analysis. PLoS One. 2013; 8(9): e74250, doi: 10.1371/journal.pone.0074250, indexed in Pubmed: 24066126.

19. Cancer Genome Atlas Research Network. Comprehensive molecular characterization of clear cell renal cell carcinoma. Nature. 2013; 499(7456): 43-49, doi: 10.1038/nature12222, indexed in Pubmed: 23792563.

20. Moretto FC, De Sibio MT, Luvizon AC, et al. Triiodothyronine (T3) induces HIF1A and TGFA expression in MCF7 cells by activating PI3K. Life Sci. 2016; 154: 52-57, doi: 10.1016/j.lfs.2016.04.024, indexed in Pubmed: 27094789.

21. Verga Falzacappa C, Petrucci E, Patriarca V, et al. Thyroid hormone receptor TRbeta1 mediates Akt activation by $\mathrm{T} 3$ in pancreatic beta cells J Mol Endocrinol. 2007; 38(1-2): 221-233, doi: 10.1677/jme.1.02166, indexed in Pubmed: 17293442

22. Davis PJ, Davis FB, Lin HY, et al. Translational implications of nongenomic actions of thyroid hormone initiated at its integrin receptor. Am J Physiol Endocrinol Metab. 2009; 297(6): E1238-E1246, doi: 10.1152/ ajpendo.00480.2009, indexed in Pubmed: 19755667.

23. McMahon S, Grondin F, McDonald PP, et al. Hypoxia-enhanced expression of the proprotein convertase furin is mediated by hypoxia-inducible factor-1: impact on the bioactivation of proproteins. J Biol Chem. 2005; 280(8): 6561-6569, doi: 10.1074/jbc.M413248200, indexed in Pubmed: 15611046.

24. Chen RN, Huang YH, Lin YC, et al. Thyroid hormone promotes cell invasion through activation of furin expression in human hepatoma cell lines. Endocrinology. 2008; 149(8): 3817-3831, doi: 10.1210/en.2007-0989, indexed in Pubmed: 18467449.

25. Thomas G. Furin at the cutting edge: from protein traffic to embryogenesis and disease. Nat Rev Mol Cell Biol. 2002; 3(10): 753-766, doi: 10.1038/nrm934, indexed in Pubmed: 12360192.

26. Barron CC, Bilan PJ, Tsakiridis T, et al. Facilitative glucose transporters: Implications for cancer detection, prognosis and treatment. Metabolism. 2016; 65(2): 124-139, doi: 10.1016/j.metabol.2015.10.007, indexed in Pubmed: 26773935.
27. Qian CN, Tan MH, Yang JP, et al. Revisiting tumor angiogenesis: vessel co-option, vessel remodeling, and cancer cell-derived vasculature formation. Chin J Cancer. 2016; 35: 10, doi: 10.1186/s40880-015-0070-2, indexed in Pubmed: 26747273.

28. Stacker SA, Achen MG. The VEGF signaling pathway in cancer: the road ahead. Chin J Cancer. 2013; 32(6): 297-302, indexed in Pubmed: 23419196.

29. Qian CN, Huang D, Wondergem B, et al. Complexity of tumor vasculature in clear cell renal cell carcinoma. Cancer. 2009; 115(10 Suppl): 2282-2289, doi: 10.1002/cncr.24238, indexed in Pubmed: 19402071.

30. Ferrara N. Vascular endothelial growth factor. Arterioscler Thromb Vasc Biol. 2009; 29(6): 789-791, doi: 10.1161/ATVBAHA.108.179663, indexed in Pubmed: 19164810.

31. Baldewijns MM, Thijssen VL, Van den Eynden GG, et al. High-grade clear cell renal cell carcinoma has a higher angiogenic activity than low-grade renal cell carcinoma based on histomorphological quantification and qRT-PCR mRNA expression profile. Br J Cancer. 2007; 96(12): 1888-1895, doi: 10.1038/sj.bjc.6603796, indexed in Pubmed: 17505508 .

32. Rioux-Leclercq N, Fergelot P, Zerrouki S, et al. Plasma level and tissue expression of vascular endothelial growth factor in renal cell carcinoma: a prospective study of 50 cases. Hum Pathol. 2007; 38(10): 1489-1495, doi: 10.1016/j.humpath.2007.02.014, indexed in Pubmed: 17597181.

33. Smits $\mathrm{P}$, Bolton AD, Funari V, et al. Lethal skeletal dysplasia in mice and humans lacking the golgin GMAP-210. N Engl J Med. 2010; 362(3): 206-216, doi: 10.1056/NEJMoa0900158, indexed in Pubmed: 20089971.

34. Roboti P, Sato K, Lowe M. The golgin GMAP-210 is required for efficient membrane trafficking in the early secretory pathway. J Cell Sci. 2015; 128(8): 1595-1606, doi: 10.1242/jcs.166710, indexed in Pubmed: 25717001.

35. Hellewell AL, Adams JC. Insider trading: Extracellular matrix proteins and their non-canonical intracellular roles. Bioessays. 2016; 38(1): 77-88, doi: 10.1002/bies.201500103, indexed in Pubmed: 26735930.

36. Jacob A, Prekeris R. The regulation of MMP targeting to invadopodia during cancer metastasis. Front Cell Dev Biol. 2015; 3: 4, doi: 10.3389/ fcell.2015.00004, indexed in Pubmed: 25699257.

37. Martínez-Iglesias O, Garcia-Silva S, Tenbaum SP, et al. Thyroid hormone receptor beta1 acts as a potent suppressor of tumor invasiveness and metastasis. Cancer Res. 2009; 69(2): 501-509, doi: 10.1158/0008-5472. CAN-08-2198, indexed in Pubmed: 19147563.

38. Bassett JH, Williams GR. Role of Thyroid Hormones in Skeletal Development and Bone Maintenance. Endocr Rev. 2016; 37: 135-87, doi: 10.1210/er.2015-1106. 